\title{
Analgesic Drugs Prescription in Geriatric and Palliative Patients in Slovakia
}

\section{R. Babela(RobertBabela)1,3, R. Didic(Richard Didic)', M. Samohyl(Martin Samohyl)2}

${ }^{1}$ St. Elizabeth University of Health and Social Science, Bratislava, Slovakia

${ }^{2}$ Institute of Hygiene, Faculty of Medicine, Comenius University in Bratislava, Slovakia

${ }^{3}$ HADM, University of Scranton, PA, USA

\section{E-mail address:}

martin.samohyl@fmed.uniba.sk

\section{Reprint address:}

Martin Samohyl

Institute of Hygiene LFUK

Bratislava

Slovakia

Source: Clinical Social Work and Health Intervention

\section{Reviewers:}

Steve Szydlowski

University of Scranton School of Education, USA

Pawel S. Czarnecki

Rector of the Warsaw Management University, Poland

\section{Key words:}

Analgesic Drugs. Geriatric Patients. Palliative Patients.

\section{Publisher:}

International Society of Applied Preventive Medicine i-gap

CSWHI 2019; 10(2): 19 - 21; DOI 10.22359/cswhi_10_2_02 @ 2019 Clinical Social Work and Health Intervention

\section{Abstract:}

Objective: The aim of this study was the evaluation of analgesic drugs prescription as an epidemiological indicator of average annual percentage change (AAPC) in geriatric and palliative patients in the period 2016-2017.

Design: Descriptive study.

Participants: Geriatric and palliative patients. 
Methods: We analysed 12,889 analgesic drugs within the period of two years (2016-2017). Epidemiological indicator of AAPC was proposed for analysis of analgesic drugs prescription.

Results: The highest percentage from all analgesic drugs under our evaluation was Acetylsalicylic Acid in $1^{\text {st }}$ half of 2017 (54.3\%) with $0.05 \%$ decrease compared to 2016 . The significant decrease or increase of the AAPC of other analgesic drugs prescription was not observed in geriatric and palliative patients.

Conclusion: The regular reassessments of analgesic drug prescriptions is in line with the regular assessment of patients' needs are required.

\section{To the Editor}

Chronic pain is often observed in elderly patients $(\geq 65 \mathrm{y}$.) with a significant economic burden on society (1) and health system. $45-80 \%$ of older people with pain reported inadequate treatment (2). Qualified help is one of the important aspects for a dying person $(3,4,5)$.

The aim was an evaluation of analgesic drug prescriptions as an epidemiological indicator of average annual percentage change (AAPC) in geriatric and palliative patients in the period 2016-2017.
The data were provided by the General Health Insurance Company. It analysed 12,889 of analgesic drug prescriptions in the period 2016-2017. The epidemiological indicator of AAPC (analysing of decline/ growth of drugs) was proposed for analgesic drug prescriptions (6). The trend of AAPC was tested by the Nonparametric Wilcoxon Test (IBM SPSS Statistics).

The AAPC of analgesic drug prescriptions in geriatric patients in the period 20162017 can be seen in Table 1 .

Table 1: The AAPC of analgesic drugs prescription $(n=12,889)$ in geriatric and palliative patients in the period 2016 - 2017

\begin{tabular}{|l|l|l|l|l|l|}
\hline Analgesic Drugs & $\begin{array}{l}\mathbf{1}^{\text {st }} \mathbf{h a l f} \text { of } \\
\mathbf{2 0 1 6} \\
\mathrm{n}(\%)\end{array}$ & $\begin{array}{l}\mathbf{2}^{\text {nd }} \mathbf{h a l f} \text { of } \\
\mathbf{2 0 1 7} \\
\mathrm{n}(\%)\end{array}$ & $\begin{array}{l}\mathbf{1}^{\text {st }} \mathbf{2 0 1 f} \text { of } \\
\mathbf{n}(\%)\end{array}$ & $\begin{array}{l}\mathbf{2}^{\text {nd }} \text { half of } \\
\mathbf{2 0 1 7} \\
\mathrm{n}(\%)\end{array}$ & AAPC \\
\hline Acetylsalicylic Acid & $1,810(54.1)$ & $1,808(53.4)$ & $1,741(54.3)$ & $1,580(53.5)$ & -0.05 \\
\hline Diclofenac & $169(5.1)$ & $138(4.1)$ & $152(4.7)$ & $146(4.9)$ & -0.06 \\
\hline Nimesulide & $59(1.8)$ & $78(2.3)$ & $70(2.2)$ & $63(2.1)$ & 0.01 \\
\hline Tramadol & $215(6.4)$ & $205(6.1)$ & $207(6.5)$ & $212(7.2)$ & -0.01 \\
\hline Metamizole Sodium & $1,049(31.4)$ & $1,126(33.2)$ & $994(31.0)$ & $922(31.2)$ & -0.05 \\
\hline Codeine & $41(1.2)$ & $32(0.9)$ & $40(1.2)$ & $32(1.1)$ & -0.11 \\
\hline SUM & 3,343 & 3,387 & 3,204 & 2,955 & -0.04 \\
\hline
\end{tabular}


The highest proportion of analgesic drugs was observed for Acetylsalicylic Acid in $1^{\text {st }}$ half of $2017(54.3 \%)$ with a $0.05 \%$ prescription decrease in 2016-2017. A decrease of analgesic drug prescriptions for Diclofenac (AAPC $-0.06 \%$; $=$ n.s.); Tramadol (AAPC $-0.01 \% ; \quad \mathrm{p}=$ n.s.); Metamizole Sodium (AAPC $-0.05 \% ; \mathrm{p}=$ n.s.); Codeine (AAPC $-0.11 \% ; \mathrm{p}=$ n.s. $)$; an increase of analgesic drug prescriptions for Nimesulide (AAPC $0.01 \% ; \mathrm{p}=$ n.s.) was found in the period 2016 2017.The significant decrease/increase of the AAPC of analgesic drug prescriptions was not observed in geriatric patients (Table 1).

A regular reassessments of analgesic drug prescriptions and the needs of patients are needed.

\section{References}

1. INSTITUTE OF MEDICINE (US) (2011) Committee on Advancing Pain Research, Care, and Education. Relieving pain in America: a blueprint for transforming prevention, care, education, and research. Washington (DC): National Academies Press.

2. American Geriatrics Society Panel on the Pharmacological Management of Persistent Pain in Older Persons. Pharmacological management of persistent pain in older persons (2009) J Am Geriatr Soc.; 57 (8): 133146. doi:10.1111/j.1532-5415.2009.02376.x.
3. DOBSONYOVA A, JANKECHOVA M, FRANKOVA M (2017) Multicultural Aspects of Palliative Care. Clinical Social Work and Health Intervention. 8 (4): 35-43. doi:10.22359/cswhi_8_4_04.

4. KOVAC R, POLONOVA J, PROCHAZKOVA K, MIKOLASOVA C, KRCMERY $\mathrm{V}$, BERNADIC M, KISAC P, KALAVSKY E, MRAZOVA M, MATEICKA F, LISKOVA A, MAMOVA A, OLAH M, HERDICS C, IBRAHIM M (2018) Absence of TB and $\mathrm{HIV}$ in sheltered homeless population of Bratislava (Slovakia) In Lekarsky Obzor. Vol 67, No 6, pp 202-203. ISSN 04574214.

5. KULASIKOVA M, COLLAKOVA M (2018) Leg support, Rehabilitation, 2018, Vol. 55, No. 1, ISSN0375-0922, p. 19 - 30.

6. NOVOTNY J, STANCIAK J (2015) Why ethics and bioethics in geriatric pharmacotherapy. In: VII. International Symposium the present and the future of nursing and midwifery. Nyiregyhaza: Debrecen University Faculty of Health, 10-20.

7. STANCIAK J, PECIOVA R (2014) Psychosocial aspects of dying from view of nurses (in Slovak). In: Nursing without borders IV. Bratislava: Slovak Chamber of Nurses and Midwives,: 272-276.

8. CLEGG LX, HANKEY BF, TIWARI R, FEUER EJ, EDWARDS BK (2009) Estimating average annual per cent change in trend analysis. Stat Med.; 28 (29): 3670-82. 